\title{
Library Digitization - A Panacea for Educational Development in Nigeria
}

\author{
Ndum, Victor Etim ${ }^{1}$, Edem Ebong ${ }^{2}$ Onukwugha Chinwe Gilean ${ }^{3}$ \\ ${ }^{1 \& 2}$ (Institute Of Public Policy And Administration, University Of Calabar, Cross River State, Nigeria. \\ ${ }^{3}$ (Department of Computer Science University Of Port Harcourt, River State, Nigeria)
}

\begin{abstract}
The need for development of education in Nigeria cannot be overemphasized. Digital library collection of documents in organized electronic form, available on the internet or on CD-ROM (Compact Dis read-only-memory) remains a veritable instrument for engendering formidable transformation of the Nigeric decaying educational system. The traditional/conventional physical library, although provides a basis for the digital library, does not possess the required speed that could position Nigeria on a platform that could enable it compete favourably with other nations of the world in the area of knowledge acquisition, preservation and dissemination. In this paper, effort is made to examine the place of digital libraries in the development of education in Nigeria. In order to appropriately tackle the challenges of library digitization identified in the paper, it was recommended amongst others that all stakeholders should be active players in the entire process of establishing and sustaining them. Librarians should begin to foresee the added roles library digitization will impose on them in an attempt to build the library for tomorrow and begin to develop themselves for such tasks. There is need to incorporate library digitization as a specialization in Nigerian library school curriculum.
\end{abstract}

Keywords- Computerization, Educational Development, Information and Communication Technology, Library Digitization, Panacea.

\section{Introduction}

Illiteracy among Nigerians, with its social and economic implications, has become a growing concern in recent times. Interestingly, the modus-operandi of all libraries is for the emancipation of mankind from the clutches of the evil mechanism of illiteracy and misinformation as it is observed that man naturally is information sick unless properly educated (schooled) in the art of information extraction and use. Without the library no meaningful academic efforts can be carried out.

Digital library is a collection of texts, images, etc, encoded so as to be stored, retrieved, and read by computer. Furthermore, a digital library is a collection of documents in organized electronic form, available on the Internet or on CD ROM disks. It is the traditional/conventional physical library that provides a basis for the digital library. Digital collections could clearly be referred to as unlimited access to document surrogates: they extend to digital artifacts that cannot be represented or distributed in printed formats.

In the last couple of years, students and lecturers in Nigerian tertiary institutions have increasingly demanded and preferred access to electronic sources delivery and networked information from their respective libraries (Covi and Cragin, 2004 in Okiy, 2010). Internet access is one of the greatest technological advancements being experienced in this 21 st century. It revolves around advancements in Information and Communication Technology (ICT) which has gone a long way to influence the mode of information gathering, storage, retrieval and dissemination in these times. Internet access is used for electronic mailing services, electronic on-line chats, group activities among others (Akintunde, 2006). It has resulted in increased access to timely, accurate, relevant and current information in most ICT compliant libraries all over the world.

The library generally enables the individual to obtain spiritual, inspirational, and recreational activity through reading, and therefore the opportunity of interacting with the society's wealth and accumulated knowledge (Omojuwa 1993). The library can be seen as an extension of education. Library services are needed to keep the skills that have been acquired through literacy classes alive by the provision of good literature. If education is to have a greater share in the moulding and building of a happier individual and a better society, the providers of education must go further than their roles as literacy facilitators to a more practical role of providing libraries for sustaining the newly acquired skills of learners. The use of digital library would make the functions of library easier, more efficient, faster and broader in scope, compared to the conventional library.

Educational development and Library are two inseparable indivisible concepts, both being fundamentally and synchronically related to and co-existent with each other. One cannot be separated from the other. None of them is an end in itself; rather both of them together are a means to an ultimate end. One dies as soon as the other perishes. One survives as long as the other exists. This twined-nature these concepts emerged from the birth of human civilization to the posterity through a process of evolution in accord with varied needs, changes, and circumstances of various stages of human life. Library has no meaning if it cannot impart 
education. A well equipped digital library is a sine qua non for the intellectual, moral, and spiritual advancement and elevation of the people of a given society.

In this paper, effort is made to examine the place of digital libraries in the development of education in Nigeria. The first part of this work considers the conceptual underpinnings of digital libraries and educational development, the second part looks at the exact situation of Nigeria, with reference to inclination towards library digitization, in the next section, the relevance of digital library in educational development is examined. Thereafter, some basic obstacles confronting library computerization are identified and policy recommendations are provided to curb the problems. Education, being the major agent of our national development and transformation cannot thrive in the midst of a growing tradition of the conventional use of libraries. Nigerian institutions must therefore align themselves with the wave of e-teaching and learning as well as making efforts directed towards the establishment and sustenance of digital libraries.

\section{Conceptual Framework}

Library digitization is a new environment for achieving an old goal. It entails the adoption of Technological Innovations in the capturing, storage, organization and preservation of library info resources. It is a process that ensures effective library and information service delivery. Library digitization is a process through which library materials are converted from the hard copies to electronic copies. Digitization is an integral part of the library's activities. According to (National Library of Australia, 2009), digitization is a process of creating digital surrogates (version) of analogue materials from the library's collection. Activity cycle for digitization includes: capturing, storage, management and long term preservation.

It should be noted that a process had led to an institution called digital library, virtual library or elibrary. While library digitization is a process; digital library, virtual library or electronic library is an institution in which collections are in digital formats and accessible by computers. The digital content may be stored locally or accesses remotely via computer networks. A digital library or virtual library or e-library is a type of information retrieval system. Digital library is an organization, which might be virtual, that comprehensively collects, manages and preserves for the long term rich digital content, and offers to its user communities specialized functionality on that content, of measurable quality and according to codified policies( Candela et al. 2008)

The term digital libraries were first popularized by the NSF/DARPA/NASA Digital Libraries Initiatives in 1994. Distinction is often made between content that was created in a digital format - born-digital, and information that has been converted from a physical medium by digitization. It should be noted that many of the libraries in Nigeria are not wholly digital libraries, but are hybrid libraries. Hybrid libraries are libraries that have both physical collections and digital collections (Okiy, 2010)

Over the decades libraries have been known as information and knowledge institutions. They are known for provision of conducive spaces and accommodation for information, education, and research to wide range of users. However, efforts are recently geared towards redesigning and re-engineering libraries and their services in order to achieve a wider range of competitive goals needed in knowledge economy; driven by technological innovations ( Ayanbode ,2011). According to (British Library of Congress, 2008), more recently, the advent of the internet and the ability to digitize large quantities of text and images and make them available over the web had transformed ways of Libraries working". In this digital age, when access to information and knowledge is on high demand in the right package, libraries as facilitators have to enhance a paradigm shift in their services. Library services ought to be an integral part of local delivery, synthesized with services for all stakeholders of different age group (adults and young people) and supporting knowledge management for personal, family, institution/organisation, community and national development. Describing the role of modern libraries for modern users; libraries are more than a building that houses books and data. The library represents a widow to a larger world, the place (without boundaries) where we've always come to discover big ideas and profound concepts that help move the human story forward.

The concept library computerization as a process originated quite some decades ago in the more technologically advanced countries of the world such as the United States of America, Canada, Great Britain (AKINTUNDE, 2002). It is observed thus that the trend has gradually transcended to other states of the world especially the impetus is more in the growing third world countries such as in the African, Asian and the Caribbean countries.

Library computerization is the process of adequately utilizing computer hardware cum software's and its varying facilities such as networking cables, software packages, scanners aid pointes in accomplishing library functions which were originally performed manually by the librarians. Obaseki (2007) stated that computers have transcended, the status of mere computing to communication as the use of computers worldwide are primarily for communication data in networked environments.

With the invention of Information and Communication Technology, libraries now use various types of technologies to aid the services they render. Everyday new technological advances affect the way information is 
handled in libraries and information centers. The impacts of new technologies are felt by libraries in every aspect. Computing technology, communication technology and mass storage technology are some of the areas of continuous development that reshape the way that libraries access, retrieve, store, manipulate and disseminate information to users. The academic library has been from its inception an integral part of institutions of higher learning, rather than an appendix or adjunct (Krubu \& Osawaru 2011)

Academic libraries could generally be likened to those libraries that are mainly found in tertiary institutions, they are established to support learning, teaching and research processes. These libraries have been affected by changes in information and communication technology over the last few decades. The rate of changes is still accelerating in this area. The introduction of various information technology (ICT) trends has lead to reorganization, change in work patterns, and demand for new skills, job retraining and reclassification positions. Technological advancement of the past twenty five years, such as the electronic database, online services, CD-ROMs and introduction of internet has radically transformed access to information. Rana (2009) opined that ICT holds the key to the success of modernizing information services. Applications of ICT are numerous but mainly it is used in converting the existing paper-print records in the entire process of storage, retrieval and dissemination.

ICT has impacted on every sphere of academic library activity especially in the form of the library collection development strategies, library building and consortia. ICT presents an opportunity to provide valueadded information services and access to a wide variety of digital based information resources to their clients. Furthermore, academic libraries are also using modern ICTs to automate their core functions, implement efficient and effective library cooperation and resource sharing networks, implement management information systems, develop institutional repositories of digital local contents, and digital libraries: and initiate ICT based capacity building programmes for library users.

Information and Communication Technology (ICT) has brought unprecedented changes and transformation to academic library and information services, conventional LIS such as OPAC, users services, reference services, bibliographic services, current awareness services, Document delivery, interlibrary loan, Audio visual services and customer relations can be provided more efficiently and effectively using ICT, as they offer convenient time, place, cost effectiveness, faster and most-up-to-date dissemination and end users involvement in the library and information services process. The impact of ICT characterized on information services by changes in format, contents and method of production and contents and method of production and delivery of information products. Emergence of internet as the largest repository of information and knowledge, changed role of library and information science professionals from intermediary to facilitator, new tools for dissemination of information and shift from physical to virtual services environment and extinction of some conventional information services and emergence of new and innovational web based.

According to Iromatu (1996) Libraries today have shifted from conventional libraries where books and other printed texts are consulted and borrowed. In line with this, Kasperek (2003) opined that computer technologies are becoming part of any library jobs especially at this 21 st century when the role of this technology in information services expands at first rate. Furthermore, the presence of Internet in libraries is accessible only with the aid of information technology and communication. Many libraries have developed sites to organize and publicize internal and external links to information. It is of note that computerization has enabled libraries all over the world to develop complex and simple globally accessible pages listing hours, locations and resources available while others have developed web layouts using a wide variety of languages.

That library computerization is a welcome change is not an over stated fact. This is so as Kline (2003) asserts that "Academic library patrons face an information landscape that is radically different from the sheltered havens that we experienced as patrons, by contrast our patrons will work in electronic environments were the boundaries between scholarly information, popular resources and outright misinformation are blurred. This have been observed to be truism as the unprecedented increase in government efforts in providing to its citizenry profitable concrete and definable educational standards is more vivid in recent years especially in African states of Nigeria, Ghana, South Africa just to mention a few. As government and its agencies has lost patience with the old ways of information resources acquisition, management and provision.

\section{The Nigerian Situation}

In Nigeria, the federal government as far back as 1983 took a loan to facilitate the provision of information/computer technologies such as CD-ROMs, and training of library personnel on its uses, for 20 universities. This stance has however over the years been improved upon as the government of Nigeria through its various agencies such as the Nigerian University Commission (NUC), the Educational Trust Funds (ETF) and the Petroleum Trust Fund (PTF) to mention a few while recognizing the aberrance i.e. importance of ICTs to educational developments in Nigeria vis-à-vis development of the information base of the citizens has contributed to the improvement of libraries. 
Accordng to Kumar and Kar (1995) NUC, the body regulating the tertiary institutions in Nigeria, sponsored, developed and purchased computer library software such as XLib, TINLIB for Nigerian university library use. In line with the above United Nations Educational, Scientific and Cultural Organization (UNESCO, 1998) reported that the ETF/PTF, since inception in 1990s till date, have continually distributed free computer hardware and software to tertiary institution libraries in Nigeria. The ETF have also built standard befitting library buildings at all the spheres of Nigeria educational system.

In addition to these, there are increases in the budgetary allocations to education vis-à-vis educational institutions and their libraries. This is so as between 1999 till date various state governments and the federal government have demonstrated their love for current and well managed ICTs information based libraries. This is revealed with the erection of an eye catching super structures as libraries, e.g. The Edo State government sponsored and erected a public library one of the first of its kind in the southern axis of Nigeria in the 1999-2007 democratic regime with all the characteristics of what makes it a modern computerized library as well as the erection of a modern academic library at the Ambrose Alli University, Ekpoma.

Also the federal government released huge financial allocation for the complication of the second phase of the Bayero University Kano Library which on its completion today stands out as a cynosure of all eyes. Though it is pertinent that the presence of ICTs e.g. computers and internet facilities, in libraries makes a library better equipped in this information age and not the physical building. This is true as ICTs has proved to be an instrument to the fastidious death of illiteracy in the developing and advanced states in the world were illiteracy is more prone especially areas such as Australia and Bulgaria; Ice Land and Fine Land, in the Antarctica; Nigeria, Togo, Ghana, Congo and Zimbabwe, in Africa; Brazil, Peru and Colombia, in South America, just to mention a few. Thus the computerization of library encourages the transfer of knowledge over physical geographical boundaries with less time and efforts in as much as enriching the information capabilities of citizens in international states.

The demand for e-learning is growing day by day. As a result, library services have taken on another dimension. In Nigeria, a notable number of academic libraries have established links with digital collections on various databases. Some of these academic libraries include: Nimbe Adedipe Library, at University of Agriculture Abeokuta which has digital links with: Access to Global Online Research in Agriculture, AGORA, Health Inter Network Access to Research Initiative, HINARI; The Essential Electronic Agriculture Library, TEEAL, E-Granary Digital Library.

Kenneth Dike library, at University of Ibadan apart from establishing links with the above databases, also has links with High wave Archive, INASP Pen Program for the Enhancement of Research Information, African Journals online, Arab Social Science Research Virtual Library, just to mention a few. University of Nigeria Library, Hezekiah Library, Obafemi Awolowo University Ile-Ife, National Open University Library Nigeria are all equally engaged in the initiatives. Recently, academic libraries of Ahmadu Bello University, University of Lagos and University of Nigeria Nsukka had establishment of virtual library through MTN initiatives.

Academic Medical libraries are not left out. Neuropsychiatry Hospital Library, Aro Abeokuta has established links with HINARI, MEDLINE. The same with UCH Library Ibadan and Psychiatric Hospital Library Yaba. An extensive literature review revealed the position of Nigeria as regards library digitization. It is evident that Nigerian libraries are still in the stage of library hybridization and have not fully harness the benefits of library digitization.

However, in Nigeria today a good number of our institutions have already put in place and are using the digital libraries already. However, this trend is more common in our tertiary institutions than at lower level schools. Those who do not have are presently in the process of establishing them, bearing in mind that education today is driven by digital innovations and our libraries- being the pivot of information and knowledge acquisition, preservation and dissemination need to conform to the tides of change.

\section{Digital Libraries And Educational Development}

Seven categories of stakeholders of library digitization have been identified, they include: Information Professionals, Customers, Parent Institution or Organization, Collaborator/Initiator Technology, Producer , Government, Library Schools. Digital resources range from archival documents to historical images to primary source materials from scientific field research. These collections may include specific learning activities or be used as resources for teachers to use. For online resources to be useful, reliable networks, universal access, and a sound IT infrastructure are also needed. Rudatebwa and Stockman (2007) observe that online resources demand electricity, PCs, Internet connectivity, and a network.

Association of Research Libraries (1995) enumerates the importance of online resources:

$>$ The resources will never be out on loan and will be available at anytime, anyplace, and anywhere 
Access is provided to more complete set of journals than, in many instances, now exist on many library shelves;

$>$ The cost of tracking the arrival of each journal issue, claiming, and periodical binding will be eliminated;

$>$ The need for added library space may decline.

$>$ Cost of retrieving and reshelving materials will be reduced.

\section{Useful Online Services in E-libraries}

Online services in e-libraries have evolved since computers were first used in education. Lang, in Ubogu (2006) identified the following as core services in e-libraries.

- The collection: a wide variety of materials in digital forms - books, journals, manuscripts, reference works, theses and dissertations, government documents, maps video, images and pictorial materials, music scores.

- The provision of information about the library's services and collection to remote users.

- Access tools: online library catalogues, subject gateways, portals.

- Services: reference services, online tutorials, on demand publishing, electronic reserve-short loan and course packs, electronic course pack, lecture notes.

- Networking and imaging technologies to support and enhance all aspects of library basic operational activities - Z39.50, repository software - Dspace, e-print, etc. Open Archival Initiative (OAI).

- Networking and imaging technologies to facilitate closer co-operation with other bodies.

- Expertise within the library for the application of new technologies to library activities and bibliographical research of all kinds.

Technological breakthrough of a nation depends on the level of education and orientation of the citizenry. The rewards occurring from education therefore include knowledge, greater employment opportunities, higher income and better future prospects. Improvement of one's environment depends on the knowledge of that environment which is a function of education enabled greatly and with more ease and speed through digital libraries.

Digital library system has supporting roles in education especially in the area of research. In developed countries, the Internet is the working tool of researchers. They use it to cross-pollinate ideas globally. Connectivity to the Internet and proper tapping of the facilities provided by it will enhance the educational development of the nation. Educational materials and programmes from the developed countries can be easily obtained from the Internet and adopted by the user. Besides, it provides a means of up-dating one's knowledge on any discipline on a daily basis.

Interestingly, computer application and use in the libraries all over in Nigeria have proved to be a magnanimous contribution to the over-all educational enhancement of all humans irrespective of social, economic, religious cum racial affiliations. This is a truism as library computerization has led to the:

a) Increase in the patronage and use of information resources at various information centers especially the library, vis-à-vis the growth in personnel information quotient of persons in the world. This is so as the provision and application of computers and its other peripherals in the library have transformed the library into digital studios were information easily could be manipulated and acquired. In addition this novel trend of library computerization attracts patrons to the library for various purposes, some for sightseeing, recreation, research etc. It is observed that the rate of library patronage especially in universities universally has increased drastically, as in case with Nigeria, were people hardly use the library in early 1990s. The situation has changed as librarians and library management now employ means to curtail the overpopulation of their libraries especially in university (academic) libraries e.g. Bayero University library were clienteles want to use, touch or have the feeling of being around a computerized digital library.

b) Increase in moral and prestige of library staffs/personnel's. In most Africa states per se the concept of who a librarian is, to the lay man outside, was subjectively dehumanizing to the library personnel: Hence they were viewed only as Book-keepers/Book sellers of little importance to the society. This reason however was owned to the decline in our level of education cum the inability of the past African states government especially the colonial authorities to shed light on the importance of libraries to educational advancement of all society as obtainable in Europe and the Americas. Recent development in the universe has precipitated the novel concept of information age, which entails that all human has to live, eat and sleep with information. It was observed that to easily get this information in the era the library has to be technologically improved, hence the gradual change from manual to computerized ways of performing all libraries functions and services. Thus the presence of these equipments in libraries attracted persons to the librarians who the patrons now see as technologist or experts in manipulating these equipments and at same time above the library staffs. On it own the egoistic attributes on the librarian have swelled as they now view themselves as information scientists/managers rather than book keepers. 
c) Faster and easier ways of getting library functions, services and activities done. Book selection and acquisition; bibliographic searching and reference services; interlibrary loans and cooperation are some of the tasks of libraries that were before now done manually i.e. with human efforts and much time. These recent trends of library computerizations have made these task a mere children game. This is so as the eventual application of computer to library has made the library work easier and faster to accomplish" (KUMAR, 1995). Also library computerization when properly applied has the tendency of breeching internationally acclaimed physical boundaries. This is truism as with the use of the international network system libraries computerized can participate in resource sharing activities amongst themselves; this will lessen the amount of funds spent in acquiring physical information resources.

d) Creation of job opportunities within the library. This is necessitated by the presence of computers and its accessories. The library has transcended to the height of an organization, in less than a decade, from the focal point of just building where books are kept. At present there are novel men job categories in libraries, especially the academic libraries such as web developers, computer instructors, maintenance officers, ICTs managers/officers, etc.

e) Computerization of libraries has provided libraries with cheaper means of purchasing information resources for their libraries. This is so as other methods were the libraries have to apply the use of manual means in selecting and acquiring its resources is more costly and involves more human efforts. Thus libraries now acquire information resources through the World Wide Web and Internet, this have made it more affordable for libraries to procure more current information resources such as journals, which are very costly when procured in physical format.

\section{Possible obstacles}

There exist some impediments towards proper library computerization. These include:

\section{i. Financial impecuniosities}

Often it has been noted that digital library management and librarians are willing and ready to make changes from the traditional method of library to novel trends, there is the negating factor of scarcity of funds. This factor over time has been viewed as a resultant posture of library management lukewarm approach to library development. Hence management exhibits their tight fist nature towards funds release for the procurement of novel library technologies and tools.

\section{ii. Dearth of Qualified Competent Librarians, with attitudinal problems.}

Libraries especially in developing countries have personnel who are not librarians by qualification. Hence these persons who function as library personnel do not have the capacity of functioning properly in a library environment thus leading to the under development of the library in function and services rendered. Digital libraries require manpower skillful in ICT .

\section{iii. Lackadaisical attitude of librarians towards rendering of service}

The future of libraries lies in the ability of librarians to collaborate with faculty. To do so, the librarian needs to be considered as an equal with faculty members. Today's librarian should develop awareness of the culture of her library and the culture in which the library exists, they should live and participate in the intellectual discourse so vital to the university community and the librarian should be constantly involved in scholarly research. In doing this, will eradicate the notion of many persons towards who a librarian is.

\section{iv. Lack of Technical Know-How/Awareness:}

Computer literacy in Nigeria is very low. The use of Internet facilities depends on one's technical know-how on the computer. Presently, in the industrialized nations, computer is a household name everywhere. While in Nigeria, not all educated Nigerians are computer literate. Most computer literates even have their knowledge restricted to the use of the computer as a word processor. This automatically means that Internet literacy is almost not in existence. An estimated number of Internet literates is about $5 \%$ of the total population. Of this percentage, $20 \%$ are Nigerians in the very high-income bracket, $30 \%$ are from National Companies and $50 \%$ from the multi-national companies.

\section{v. Poverty Level of the Citizenry:}

Poverty level in Nigeria is high. Connectivity of individuals to the global village (Internet) is very expensive for the average Nigerian. He needs close to N100,000 (\$1163) to purchase a computer and about $\mathrm{N} 64,000$ (\$744) to install telephone services excluding the cost of installing Internet facilities.

Other impediments include: Inadequate library legislation, submissive attitudes of library heads, autocratic/dictatorial stance of library parent management. Furthermore, Amekuedee (1995) stated that barriers 
to successful library computerization in Ghana include: Lack of cooperation among university libraries, attitudinal problems among librarians; and Personnel problems. These problems are also akin to the Nigerian situation.

Once these above hindrances are tackled librarians and libraries, all over the globe will definitely take a deep breath of satisfaction as result of the habitable atmosphere created by library computerization.

\section{Conclusion}

Academic libraries play very significant role of providing the necessary information to the teachers and students to achieve their teaching, learning and research needs in the easiest, fastest and most comprehensive way. This central place of the library in academics has resulted over the years in the necessity for academic libraries to continue to evolve and move with the times so that they can deliver on the requirements of academic libraries in meeting the academic needs of their clientele in schools. This need has resulted over the years in the libraries in Nigeria displaying different stages of development in the application of Information and Communication Technologies (ICT), to library services.

The current trend in many libraries worldwide is the deployment of ICT facilities in rendering services of various kinds to their patrons thereby providing speedy and up-date information for their use. Glaringly, the modus-operandi of all libraries is for the emancipation of mankind from the clutches of the evil mechanism of illiteracy and misinformation. Man generally is information sick unless properly educated (schooled) in the art of information extraction and use. The digitization of libraries remains a suiting option that could enable the development of education in Nigeria and other parts of the world.

\section{Recommendations}

In other to tackle the obstacles identified above and to ensure effective use of digital libraries in Nigeria and elsewhere in the enhancement of education, the following recommendations are worthwhile.

- All stakeholders should be active players in the entire process of establishing and sustaining digital libraries. For instance, Librarians should begin to foresee the added roles library digitization will impose on them in an attempt to build the library for tomorrow and begin to develop themselves for such tasks.

- Librarians and academicians should collaborate to evaluate and provide links to authoritative web resources related to programmes and courses taught. There is need to also incorporate library digitization as a specialization in Nigerian library school curriculum.

- More generous financial support should be made available to provide the basic ICT infrastructural facilities. The assistance of some donor agencies such as Education Trust Fund (ETF) and Open Society Initiative for West Africa must be actively enlisted

- Since Information and Communication Technology (ICT) has come to stay, library staff that are not computer literate should take positive steps to remedy their deficiencies so as to flow along with the reforms. By this, library and information services will become ennobled through the acquisition of adequate ICT knowledge/skill and its full application in Nigerian University Libraries or else they will become irrelevant in this era of ICT.

- Effective and efficient power supply supplemented with standby generators should be provided to check the menace of frequent electricity power failure. In the same vein, the government should address the problem of erratic power supply more seriously not through military order but through research and development.

\section{References}

[1] Covi, M.L. and Cragin, H.M. (2004). reconfiguring control in library collection development: a conceptual framework for assessing the shift toward electronic collections. Journal of American Society and Technology, 55(4):312- 325 Okiy R. (2010) Globalization and ICT in academic libraries in Nigeria: The way forward. Available http://www.webpages.uidaho.edu/ mbolin/okiy.htm

[2] Akintunde, S.A. (2006). State of ICTs in tertiary institutions in Nigeria: Window on the Universities. in compendium of papers presented at the 44th annual national conference and AGM of Nigerian Library Association, Abuja. 18-23 June 123-137

[3] Omojuwa, R. A (1993) Directions I adult literacy programming in Nigeria, literacy and reading in Nigeria, Reading Association of Nigeria, (7) pa. $2007-214$.

[4] National library of Australia (2009) Collection digitization policy. Retrieved December 5, 2010 .from www.nla.gov.au/policy/digitization.html

[5] Candela'L. et al. (2008) The DELOS digital library reference model- foundations for digital libraries. Version 0.98,PDF (http://www.delos.info/files/pdf/ReferenceModel/DELOS_DLReferenceModel_0.98.pdf)

[6] Ayanbode , O.(2011) Library Digitization: A strategy to bridge information and knowledge divides Availablehttp://www.eurojournals.com/EJSR_56_2_09.pdf/17/2012

[7] British library board. (2008) Digitization strategy 2008-2011. Retrieved December 5, 2010 from www.bl.uk>----> the digital programme> Digitization.

[8] AKINTUNDE, S. A. (2002) Say it again: We just took off. Nigeria libraries, v.36, n.2, p.1-6, OBASEKI, T. I. (2007) Educational development in Nigeria: Fighting illiteracy and promoting literacy through the elementary school system (Problems and Strategies). 
Journal of Educational Research and Development, v.2, n.3, p.64-67, Krubu D. and Osawaru F (2011)the impact of information and communication technology (ict) in Nigerian university libraries.. Available -http://www.webpages.uidaho.edu/ mbolin/krubuosawaru.htm Rana, H.K. (2009) Impact of information and communication technology on academic libraries in Punjab. Source: http/www.goarticles.com/cgi-bin/showa/cgi? =1239032. Retrieved 20/10/2012

[9] Iroamatu, o. c. (1996) Challenges and opportunities for information revolution in Nigeria. in: National conference and annual general meeting of Nigerian library association. Abuja: Nigerian communication commission.

[10] Kasperk, S. (2003) Technology skills in libraries of 21 st century: in expectorations of libraries in 21st century. London: Greenwood,. p.69-71

[11] Kline, V. (2003) A word for future academic librarians: In expectorations of libraries in 21st century. London: Greenwood p.7375Kumar,S. Kar, D. C. (1995) Library computerization: An inexpensive approach. Book Review, v.44, n.1, p.45-55, UNESCO (2008) The state of education in Nigeria. Lagos; Lagos Office, Ubogu, F. N. (2000) The paperless society: farce or reality. African journal of library and archives and information science. 10(1), $13-21$.

[12] Amekuedee, J. O.(1995) Barriers to successful university library automation in Ghana with particular reference to balme library. International library review, v.27, n.2, p.171-181, 